UDC 75.036.45(477)"19"(092)

DOI https://doi.org/10.24919/2308-4863/36-2-8

\author{
Oksana MOSENDZ, \\ orcid.org/0000-0003-1268-2179 \\ Graduate Student at the Department of Theory and History of Arts \\ Kharkiv State Academy of Design and Arts \\ (Kharkiv, Ukraine), \\ Lecturer at the Department of Art Studies \\ Dnipro Faculty \\ of Kyiv National University of Culture and Arts \\ (Dnipo,Ukraine) mosendz.oxana@gmail.com
}

\title{
SYMBOLICS OF COLOUR IN THE PAINTING OF UKRAINIAN SYMBOLIST ARTISTS OF THE EARLY 20th CENTURY
}

The article is devoted to the analysis of the symbolics of colour in the paintings of Ukrainian symbolist artists of the early 20th century. The problem posed was studied using the example of the work of Yukhim Mikhailov and Mikhail Sapozhnikov, the largest number of whose works were painted in the spirit of symbolism. The study used art historical methods - iconographic, iconological, semiotic, as well as general scientific methods-description, analysis, comparison, generalization. In the process of work, the principles underlying the creation of an artistic image by symbolist artists were studied. The role of colour as a symbol in painting is determined. The characteristic features inherent in the Ukrainian symbolism of the beginning of the 20th century are highlighted, its symbolic and colouristic features are determined. It was noted that the works of Ukrainian artists are filled with a deep philosophical meaning, which does not lie on the surface, but opens layer after layer with a long and careful examination. At the same time, it was found that the colouristic features of the paintings help the authors in conveying the meaning, idea, plot of the picture. It was revealed that the colouring of the paintings of the Ukrainian symbolists is the main psychological and emotional component of the artistic image. It was found that the colouration of the paintings is inherent in conventionality, decorativeness, the use of unnaturalistic colour solutions. It has been established that one of the features used by Ukrainian symbolist artists was synesthesia - a combination of picturesqueness, musicality, lyric poetry in one work. In the process of analysis, we found that the era of revolutions and global cultural changes brought new meanings into the symbolics of colour, the reflection of which we see in the paintings of Ukrainian symbolist artists of the early 20th century.

Key words: symbol, symbolism, Ukrainian artists, painting, colour, colouration.

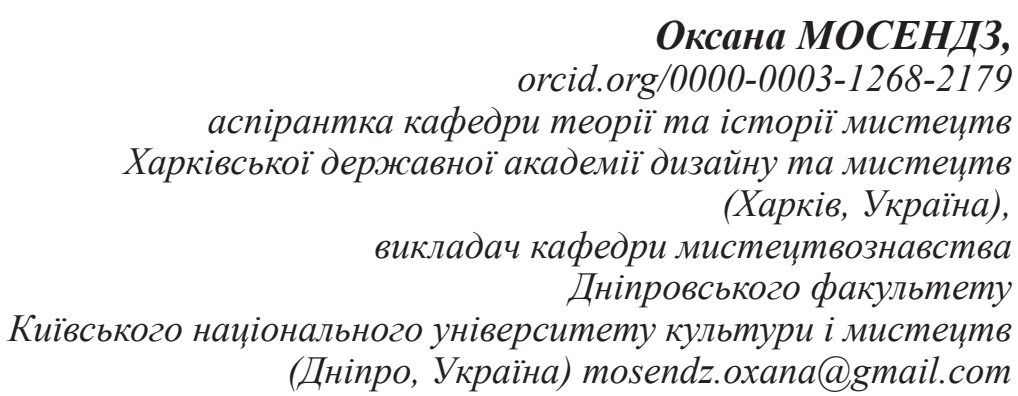

\section{СИМВОЛІКА КОЛЬОРУ В ЖИВОПИСУ УКРАЇНСЬКИХ ХУДОЖНИКІВ- СИМВОЛІСТІВ ПОЧАТКУ ХХ СТОЛІТТЯ}

Стаття присвячена аналізу символіки кольору в живописних творах українських художників-символістів початку XX cm. Порушена проблема вивчалася на прикладі творчості художників Юхима Михайлова і Михайла Сапожнікова, більшість робіт яких була виконана в дусі символізму. У дослідженні застосовувалися мистеиттвознавчі методи (іконографічний, іконологічний, семіотичний), а також загальнонаукові (опис, аналіз, порівняння, узагальнення). Символісти початку ХХ століття в пошуках способу передачі своӥх думок, настрою, стану душі наповнювали символічним значенням усі складники художніх творів, в тому числі, колір в картинах. Для символізму, в тому числі в живописі, характерна відмова від зображення сучасного життя, тяга до середньовіччя, пріоритет міфологічних і біблійних сюжетів, тема любові і смерті. У процесі роботи були вивчені приничипи, щчо лежать в основі створення художниками-символістами художнього образу. Визначено роль кольору як символу в живописі. Виділено характерні риси, притаманні украӥнському символізму початку ХХ ст., визначені його символіко-колористичні особливості. Було зазначено, щзо роботи украӥнських художників наповнені глибоким філософським змістом, який не лежить на поверхні, а відкривається пласт за пластом у процесі тривалого 
й уважного розгляду. При и̧ьому було встановлено, щзо в передачі сенсу, ідеї, сюжету картини авторам допомагає колористична гама картин. Виявлено, щзо колорит картин украӥнських символістів є основною психологічної та емоційної складової частини художнього образу. 3'ясовано, щзо колориту їхніх картин притаманні умовність, декоративність, використання ненатуралістичних колірних рішень, особливе значення в картині набуває колірний контраст. Встановлено, однією з рис, які використовуються украӥнськими художниками-символістами, була синестезія - поєднання в одному творі мальовничості, музикальності, поетичності (лірики). У процесі аналізу нами з'ясовано, щуо епоха револющій і глобальних культурних змін принесла в символіку кольору нові ідеї, відображення яких ми спостерігаємо в картинах украӥнських художників-символістів початку XX ст.

Ключові слова: символ, символізм, українські художники, картина, колір, колорит.

The formulation problem statement. The symbol system is an integral part of the culture. One of the features inherent in the symbol is to permeate the culture from the past to the future, to connect the times with each other, which makes its study constantly relevant. Symbolist artists of the early twentieth century, in search of a way to convey their thoughts, mood, state of mind, used the symbolic meanings of colour. The creative work of Ukrainian artists working in this style direction had a number of its distinctive features, including in colouration. In this work, based on the analysis of paintings, literary sources, with the help of art history and general scientific methods, one of the little-studied aspects of symbolism is investigated - the symbolics of colour in the painting of Ukrainian symbolist artists of the early twentieth century. To solve this problem, a number of paintings by Ukrainian artists Yukhim Mikhailov and Mikhail Sapozhnikov were analyzed, the largest number of works of which was painted in the spirit of symbolism.

The analysis of conducted studies. A number of outstanding philosophers and art critics have dedicated their works to a deep and comprehensive disclosure of the concept of a symbol - I. Kant, C. Pearce, E. Cassirer, Y. Lotman, A. Losev, N. Rubtsov and others. The theme of symbolics of colour in icon painting, which was formed in the Middle Ages, is revealed in his works by D. Stepovik (Stepovik, 1996: 19, 25). A significant contribution to the theory of colour was made by the philosopher and writer of the Enlightenment I. Goethe. In his work "Teaching about Colour", Goethe paid great attention to the emotional impact of colour. He believed that colour in painting could be used to contribute higher aesthetic goals (Goethe, 2019: 58). V. Kandinsky in his work "On the Spiritual in Art" assesses the psychic power of paint as causing a vibration of the soul (Kandinsky, 2019: 44). K. Malevich in his articles pays great attention to the role of colour and the power of its influence (Malevich, 2014: 69). The artist, educator, writer, creator of the colour theory J. Itten, in the book "The Art of Colour", focuses on the symbolic meaning of colour (Itten, 2018: 83). V. Palmov (Palmov, 1929) and A. Bogomazov (Bogomazov, 1996) paid great attention to the role of colour in painting in their theoretical works. In his articles published in 1929 in the journal "New Generation", Palmov expresses the idea of the primary role of colour in painting (Palmov, 1929: ....). In their books, N. Volkov, J. Agoston, J. Balek, M. Surina and other authors diversify the theme of colour in painting. A series of books, each of which is devoted to the history of a particular colour, was written by M. Pasturo. A number of articles on the role of colour in painting were published by E. Avakumova, O. Beldiy, O. Otich, P. Grechanovskaya, Z. Tkanko, P. Sotnik, V. Vovkun and other authors.

The purpose of the article is determination of the peculiarities of the colouration of paintings, as well as the role of the symbolics of colour in the painting of Ukrainian Symbolist artists of the early 20th century, using the example of a number of works by Yukhim Mikhailov and Mikhail Sapozhnikov.

Main body. The beginning of the 20th century were filled with upheavals and commotions in world history and culture. Grandiose scientific discoveries, technological achievements, a new, fast-paced rhythm of life - all this, like a stormy stream, shook and demolished old traditions in its path. Artists, poets, writers, rejecting established academic art, were looking for new forms of expression in various directions of modernism. One of the first directions of modernism, which arose in the works of French poets in the 1870s and left a bright mark on the art of the late XIX - early XX centuries, was called symbolism.

Undoubtedly, the concepts of symbol and symbolism existed before the 19th century. In the era of antiquity in philosophy and aesthetics art is analyzed through the problems of a symbol, a sign. In all subsequent eras, historians, artists, scientists have repeatedly raised the theme of the symbol (Basin 2012: 12). Nevertheless, the problem of the symbol continues to be relevant in our time. In this work, we will touch upon one of the little-studied problems of symbolism - the symbolic meaning of colour in the painting of Ukrainian Symbolist artists of the early twentieth century and analyze the artistic and stylistic features of the work of the authors, the largest number of whose works were executed in the 
spirit of Symbolism - Yukhim Mikhailov and Mikhail Sapozhnikov. To solve this problem, we first review the basic principles and techniques of the studied artistic painting direction.

According to the symbolists of the late 19th and early 20th century, the artist's inner world, his ideas, attitude could not be fully expressed with the help of traditional rational artistic means - classical composition and perspective, realism in the plot, linear drawing, naturalistic colouration. To convey their thoughts, moods, state of mind, they used symbols, while filling with symbolic meaning all the components of works of art - the colours of paintings, the sounds of music, the sounding of poetry (Lotman, Mints, 1989: 43).

Symbolists paid particular attention to colour, trying to give their own picture of colour perception (Surina, 2010: 138), assigning a symbolic meaning to colour, which manifested itself in emotional colouring, convention of colour, the use of faded, "foggy" colours, the use of unnaturalistic colour solutions. Often, in a different context, the same colours acquire directly opposite meanings. N. Rubtsov cites as an example how in different paintings the blue colour symbolizes different emotions: "For example, in one picture, the blue colour is a symbol of the sky, joy and purity, it is soft, calm and gently transparent, on the other it is a symbol of sadness, longing, even hell, it is coldly prickly, unpleasant and frighteningly bottomless" (Rubtsov, 1991: 122).

Their works were saturated with hints and innuendos, the interweaving of the real with the fantastic, the atmosphere of mystery. In the book "Art and Philosophy" V. Bransky focuses on the fact that the symbolic approach to broadcasting is not only different from the realistic approach, but for it there is an opposite and the orientation to search for the mysterious all over the world is the most important feature of the symbolist ideal (Bransky, 1999: 378). The most important aspect of the worldview of symbolism was the priority of fantasy over reality, intuition and the unconscious over the rational. Symbolism, including in painting, is characterized by a rejection of the image of modern life, a craving for the Middle Ages, the priority of mythological and biblical subjects, themes of love and death. The appeal to the archaic, to the poetics of legends and tales, to the ancient myth was realized from within the symbolist culture (Azizyan, 2003: 24).

The symbolist artist includes the viewer in the creative process, expecting cooperation, in-depth intellectual work, creative interaction with the painting, intromission into the very depth of the author's thought. In his article "On Symbolic
Creativity in Art" M. Sapozhnikov wrote: "The contemplation of symbolic images can only be active. The viewer needs to put effort, the ability to fill a symbolic image with this or that content and depending on this receive certain thoughts, moods, experiences... In the symbolic image the viewer is left with a wide field for personal creativity" (Kulichikhin, 2018: 156)

We can see the manifestation of the symbolics of colour in symbolism in an attempt to convey emotions in poetry through a colour equivalent. (Adaskina, 2003: 17). A vivid illustration of these searches is the sonnet of Arthur Rimbaud, who believed that each letter has a certain colour value, and each colour contains a secret meaning, a certain emotional colouring. In the Vowels sonnet, he expressed his colour and sound associations, the correspondence between vowels and colours (Rimbaud, 1988: 148).

It is necessary to highlight another point characteristic of the aesthetics of symbolism - the manifestation of synesthesia, the idea of synthesizing colour and music, combining in one work painting and musicality. V. Bransky in the book "Art and Philosophy" reveals a fundamental similarity between a painting and a musical work - an expressive combination of graphic and colour elements is the same bearer of human experiences as an expressive combination of sounds. Therefore, any artistic image in the field of painting has some sort of "musicality" (Bransky, 1999: 107). Examples of such "musical" painting are the works of John Whistler, who called individual paintings symphonies or nocturnes "Symphony in grey and green. Ocean", "Nocturne in blue and gold. Valparaiso", "Nocturne in blue and gold. The Old Battersea Bridge". Paul Signac gave his works the names "adagio" and "scherzo", and Mikalojs Čiurlionis - "sonatas", "allegro", "andante" and "prelude and fugue". The outstanding Ukrainian artist, Cubo-futurist Alexander Bogomazov, in his treatise "Painting and Elements", painted in 1914, paid much attention to the inextricable link between colour and music (Bogomazov, 1996: 51).

Turning to symbolism in Ukrainian painting at the beginning of the twentieth century, we would like to recall that in Ukraine this artistic movement was formed not only under the influence of the outside. M. Lotman writes about the roots of symbolism in Ukrainian culture in his work "The Main Trends of Russian Modernism": "In 1884, an attempt was made in Kiev to create the New Romantics society, which was pre-modern in its orientation. Two of its members, Nikolai Minsky (real name is Vilenkin; 1855-1937) and Jerome Yasinsky (1850-1931) already created essentially decadent works" (Lotman, Mints, 1989: 46). 
Ukrainian painting at the beginning of the 20th century is rich in the names of world-famous contemporary artists. Of the authors, the largest number of whose works were carried out in the spirit of symbolism, we would like to single out Yukhim Mikhailov and Mikhail Sapozhnikov.

Having carried out a comprehensive art history analysis of the works of Ukrainian Symbolist artists, as well as using such general scientific methods as description, comparison, generalization, the method of inductive inference, we were able to highlight the features inherent in Ukrainian symbolism of the period under consideration, including its symbolic and colouristic features:

1. All works are filled with a deep philosophical meaning, which does not lie on the surface, but opens layer by layer under a long and careful consideration. The colouristic gamut of paintings helps to understand the depth of thought laid down by the author. Depending on the idea, a certain symbolic meaning is assigned to colour. For example, the work of M. Sapozhnikov "In the Gulf", from the first symbolic series "Ghosts" of 1906-1916, fascinates, does not let go, envelops with the overflows of blue. In the picture we see: the symbolists' favourite time of day is twilight, on the brink with night, on the horizon is the shore contour formed by rhythmic, soft lines, overhanging heavy clouds, a calm, luminous sea. In the center is a fantastic monster whose skin shimmers and flashes with lights. In the foreground are the contours of cypress trees.

Being a deeply spiritual person, for each of his symbolic work, the author gave a key quote from the Bible. When analyzing the symbolic paintings of Ukrainian artists of the beginning of the twentieth century, it is necessary to take into account the crucial, dramatic time of their writing. The author offers the viewer his vision of the spiritual tragedy of a man in this period. Sapozhnikov pictures a city, with its temptations and sins, as a symbolic monster with an insidious grin on his lips. Flickers of electric lights attract weak human souls like moths to the light. Fascinated and absorbed by the monster city, they are corrupted and can no longer and do not want to break out of the city nets that have entangled them. The cypress in the foreground resembles a monk with its outlines and is perceived as a symbol of the prophesying Jeremiah, warning about the divine punishment for sins. The compositional construction of the picture, the alternation and contrast of linear rhythms and volumes, and, of course, the symbolism of the colour palette form an artistic image. Looking at the work of M. Sapozhnikov, we can recall the lines of V. Kandinsky from the book "On the spiritual in art" that the deeper the blue becomes, the more it calls a person to the infinite, and awakens in him a longing for the immaculate and, in the end, to the supersensible (Kandinsky, 2019: 78) A variety of shades of deep blue envelop our consciousness and do not let go, drawing us deeper into the space of the picture...

Another colouristic palette was implemented in the work of Y. Mikhailov "The Chained Art". The work was painted in 1925. The artist's subtle mental structure foresaw the impending tragedy of the "executed revival". A powerful centuries-old oak, depicted against the backdrop of an endless Ukrainian expanse, is entangled in a heavy chain. The meaning of the painting is dramatic, but nevertheless it does not create a psychological image of hopelessness, and this is due, first of all, to the light colour scheme. In the background, the sun rises and colours the vast expanses of Ukraine with tints and nuances of warm colours. A strong wind, under which thin trees bend, is not even able to move a mighty oak. Young branches tremble in the wind, foliage does not withstand and breaks, but the oak trunk, deeply rooted in the soil, fed by national sources, grows and gets stronger. And in the soul the hope is born that chains will someday fall. We can conclude that thanks to the symbolism of warm, golden sun tones, gliding along the plane of the picture, thanks to the pastel colouration, we get an emotional mood for positive with a dramatic plot.

2. The colouration of the paintings of Ukrainian Symbolists is the main psychological and emotional component of the artistic image. The example are two paintings that convey emotion very subtly "Sorrow" by Yu. Mikhailov and "Anxiety" by M. Sapozhnikov. In both works, there is no plot as such, but, nevertheless, thanks to the symbolism of the colour, the paintings are emotionally filled. Looking at the foggy, dull, darkened blue colour, enveloping the entire space of the painting "Sorrow" by Yu. Mikhailov, we recall the ideas of J. Itten about the symbolism of blue. He believed that when blue is shaded, its dull colour causes us a sense of superstition, fear, a sense of lostness and sadness, but at the same time, this colour always indicates the path to the supersensible-spiritual, transcendental (Itten, 2018: 88). V. Kandinsky wrote about the psychological influence of grey in "On Spiritual in Art" that the transition from blue to grey affects the viewer even more depressingly, as grey is a hopeless stillness. The darker the grey, the greater the preponderance of suffocating hopelessness. When lightening, something like air enters the paint, the possibility of breathing, and this creates a well-known element of hidden hope (Kandinsky, 2019: 84-85). 


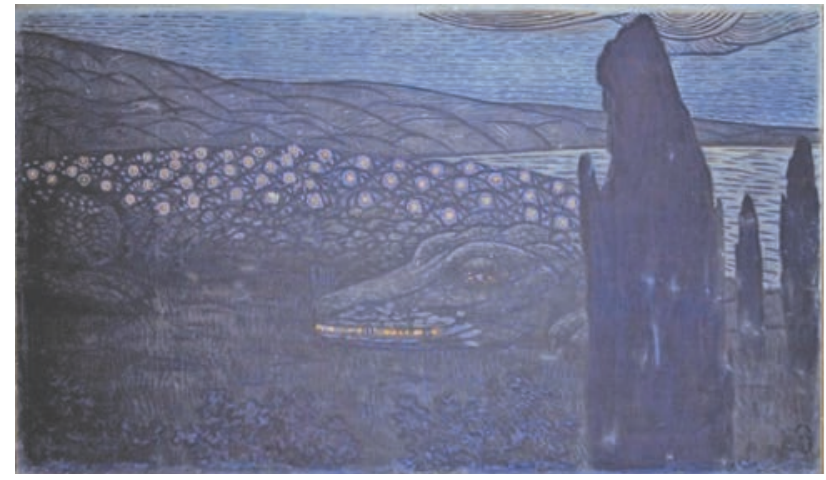

Fig. 1. M. Sapozhnikov, In the Gulf. Series No. 1 "Ghosts" (1906-1916). Canvas, glue paints, 104x177. Dnepropetrovsk Art Museum

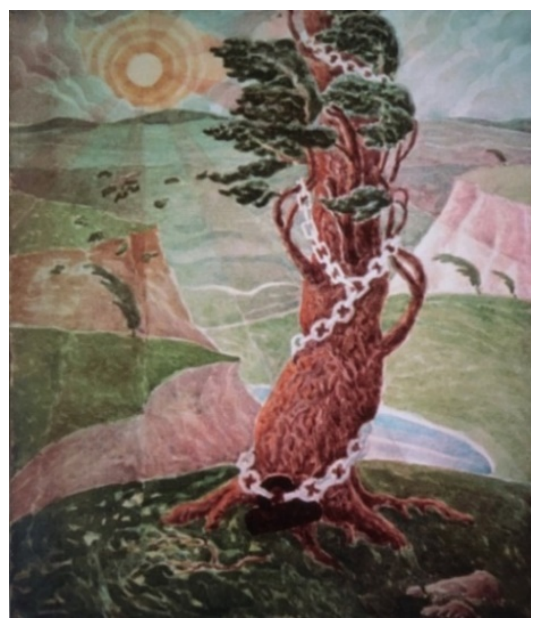

Fig. 2. Yu. Mikhailov, The Chained Art, 1925, watercolour, 46x39,5 finding not known reproduction from the book "Yuchym Mykhailiv. Life and work" Pyadik, 2003

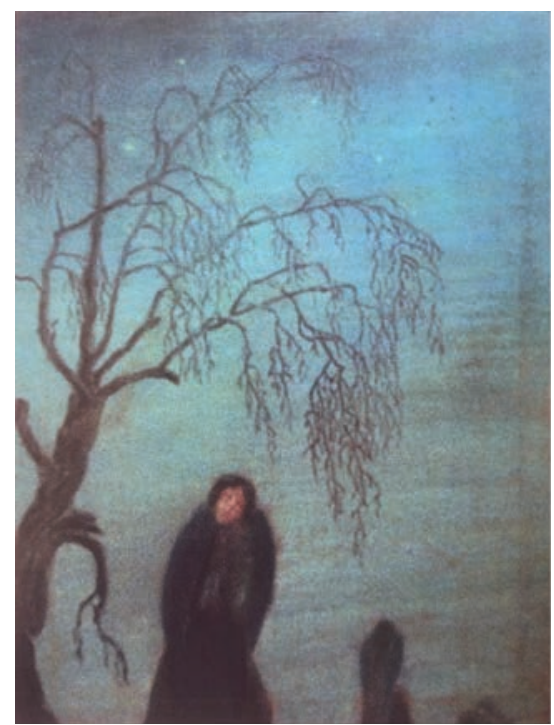

Fig. 3. Yu. Mikhailov, Sorrow, 1927. Pastel, 68,5x51b. Personal collection of the Chaplenkov family. Book reproduction "Yuchym Mykhailiv. Life and work" Pyadik, 2003

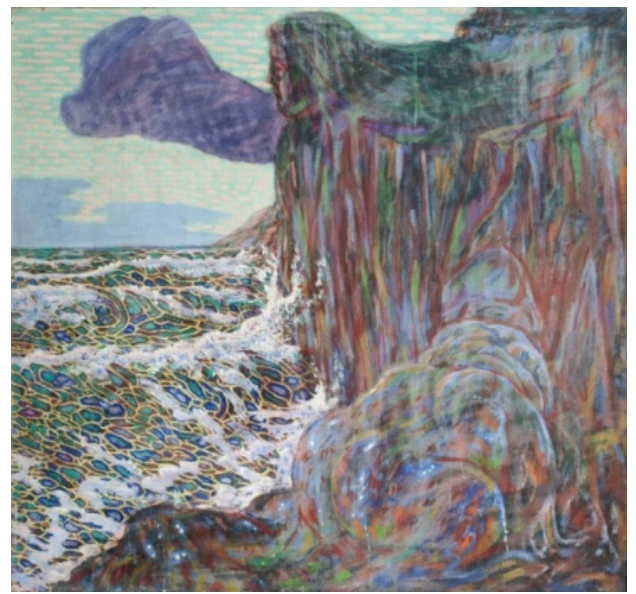

Fig. 4. M. Sapozhnikov, Anxiety. Series No. 2 (1917-1924). Canvas, glue paints, 101x105.5. Dnepropetrovsk Art Museum

M. Sapozhnikov, in his painting "Anxiety", used an alternation of different shades of warm and cold colours to convey his emotional state. This technique, combined with the linear rhythm of the painting, the contrast of the shapes of colour spots, created a kind of subtle vibration, which, upon closer analysis of the picture, receives an echo of tension, tremor, expectation, anxiety in the soul.

3. Conventionality, decorativeness, sometimes completely unexpected colour score is inherent in the colouration of the paintings of Ukrainian masters. In the painting "The Man Sleeps," M. Sapozhnikov places his character in the abyss of the sea, surrounding him with fantastic marine inhabitants. V. Turchin writes that the symbolists had a special theme for dreams and visions. (Turchin, 2012: 122). The enveloping, endless depth of anxious sleep is conveyed in blueviolet colour with grey reflections. The penetration of a single colour is symbolic everywhere - a person completely immerses in a dream and merges with the background. In a dream, a person becomes defenseless, helpless, lonely, surrounded by fantastic nightmares. But the golden ray of sunlight breaking through the abyss symbolizes awakening, the continuation of life.

4. The creative work of Ukrainian Symbolists is also characterized by the previously mentioned feature of symbolism - the combination of pictoriality and musicality in one work. In his article, M. Sapozhnikov wrote: "Rhythm plays a major role in music, partly in literature, but it is, as it were, in a frozen form and in the visual arts - architecture, sculpture and painting. The rhythm in all these arts is a cosmic phenomenon. The arts, embodying rhythm in their works, are the sacred links connecting us to the universe. Symbolic works based on rhythm are the sounds of the great, radiant, life-giving symphony of the universe and no 
matter how deaf and unclear these sounds are, they open the veil of reality and bring us to the beginning of all beginnings burning with inexhaustible creative power" (Kulichikhin, 2018: 157)). Being musically gifted, playing the violin and cello, Sapozhnikov filled all his works with musical rhythm and colour harmony.

Yu. Mikhailov's art is permeated with lyric and music - he wrote poetry, led a soldier's choir in military service, was invited to organize a church choir in Yekaterinoslav, and headed the M. Leontovich Music Society. Also, there was information that he wrote music. Significant for the creativity of Yu. Mikhailov was his visit to the exhibition of M. Churlenis in 1916. This contributed to the shaping of his searches in the field of "musical symbolism" (Pyadik, 2003: 188). The deep symbolism of the Lithuanian and Ukrainian artists was formed on the same basis - the synthesis of music and painting "synesthesia" (Sokolyuk, 2009: 491). Perceiving the world musically, he reflected his feelings in painting the triptych "Sonata of Ukraine" (1916), the painting "Music of Stars" (1919), "Poetry of the Night". He called one of his last pastels "Moonlight Sonata". It is no coincidence that V. Miyakovsky named his article about Yu. Mikhailov "Music and the poetry of colours" (1944).

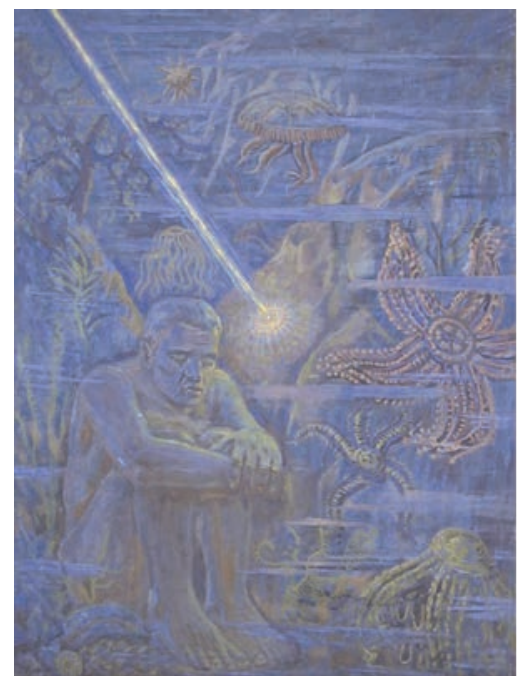

Fig. 5. M. Sapozhnikov, A man is sleeping. Series No. 2 (1917-1924). Canvas, glue paints, 133x97,5. Dnepropetrovsk Art Museum

5. M. Sapozhnikov and Yu. Mikhailov, having accepted the revolution, living and creating in an era that rejects religion, were nonetheless deeply spiritual, religious people. The symbolism of Yu. Mikhailov was fueled by spiritual sources. In 1912, while being in military service in Yekaterinoslav (now Dnipro), Mikhailov painted the pendentives of the Church of the Exaltation of the Holy Cross. Unfortunately, the church was rebuilt, and the murals, although still preserved, are in a very damaged state. But even in this form, the frescoes amaze with their strength and symbolism. With the same strength, the eyes of the apostles look at us questioningly and invitingly.

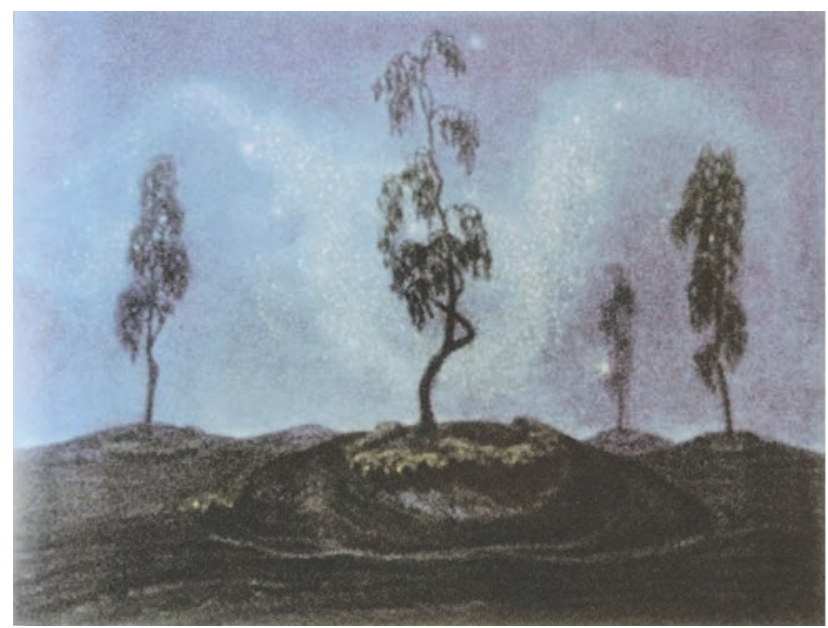

Fig. 6. Yu. Mikhailov, Music of the Stars, 1919. Pastel, 47x61. Personal collection of the Chaplenkov family. Book reproduction "Yuchym Mykhailiv. Life and work" Pyadik, 2003

We have already mentioned that M. Sapozhnikov, for each of his symbolic paintings, gave a key quote from the Gospel. So, for example, he gives the key to the painting "The Prayer of the Waves" - "... unless one is born of water and the Spirit, he cannot enter the Kingdom of God ... John, 3:5". Looking at the picture there is a feeling of the mystery of prayer, supplication to God. In the rhythmic image of the waves, silhouettes of maidens with hands raised in a prayer can be seen. In the figures rushing towards the castle, one feels tension, hopelessness, despair. The obstacles on the way to the luminous windows of a castle standing on a hill are lined up cypress trees, contours of which resemble monks. Sapozhnikov depicts a difficult path to spirituality, to God by using the symbolic language of painting. Of particular importance in the picture is the colour contrast - a deep dark blue, symbolizing the darkness of spirituality, and the bright yellow colour of the divine. I. Itten believed that if in a composition based on the contrast of light and dark, the greater dark part contrasts with the smaller light part, then thanks to this contrast the work can acquire a particularly deep meaning (Itten, 2018: 63).

6 . The beginning of the 20th century - the time in which artists lived - undoubtedly left its mark on the colouration of their works. The era of revolutions, coups, global changes in worldview is associated with red, scarlet colour. Associating with the planet 
Mars, red colour is connected with the ideas about wars and demonic worlds. The flags of the revolutions were also painted red-orange (Itten, 2018: 87). It is characteristic that in M. Sapozhnikov's second series of symbolic paintings of 1917-1924, painted under the impression of the 1917 revolution, dramatic flashes of red appear. For example, in the work "Dawn" M. Sapozhnikov, allegorically depicting the dawn of a new life, puts the main emphasis on the symbolic sounding of scarlet.

Unfortunately, the work "The Red Stallion" by E. Mikhailov, which came to us only in black and white, has not been preserved. The student of the artist E. Yankevich, who saw the original picture, created its reconstruction. Thanks to the symbolism of red, we feel the strength, energy of the horse, associated with the revolution, with a new life, detached from previous traditions. The contrast of the crimson tearing up into the blue distance of the colour spot leaving behind a dark spot of the past makes a very strong psychological impression.

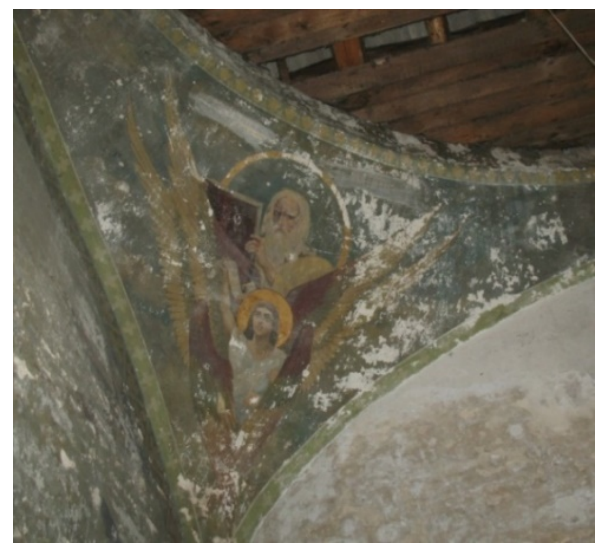

Fig. 7. Yu. Mikhailov, The Apostle Matthew, 1912. Fresco painting the pendentives of the Church of the Exaltation of the Holy Cross (regimental) in Yekaterinoslav (Dnieper). Author's photo

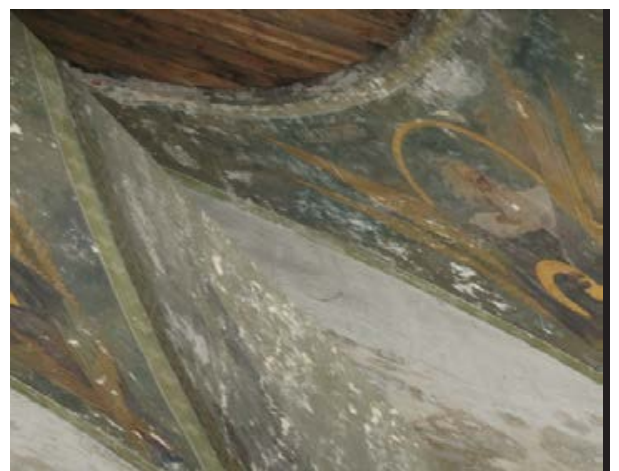

Fig. 8. Yu. Mikhailov, The Apostle John, 1912. Fresco painting the pendentives of the Church of the Exaltation of the Holy Cross (regimental) in Yekaterinoslav (Dnieper). Author's photo

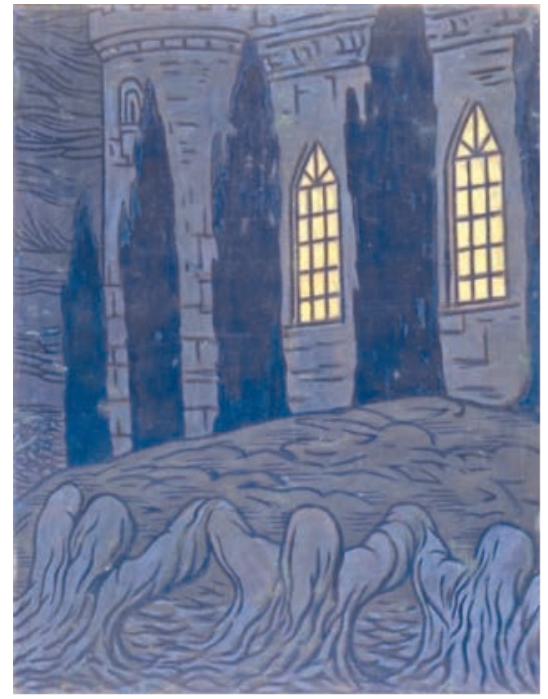

Fig. 9. M. Sapozhnikov, The plea of the waves. Series No. 1 "Ghosts" (1906-1916). Canvas, glue paints, 143x84. Dnepropetrovsk Art Museum

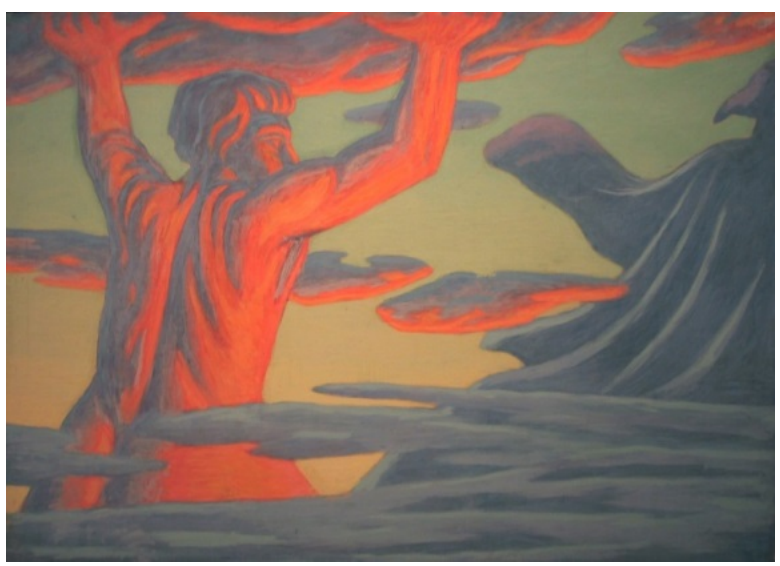

Fig. 10. Dawn. Series No. 2 (1917-1924). Canvas, adhesive paints,

128x178. Dnepropetrovsk Art Museum

To paint symbolic paintings in the Soviet Union in the thirties - for this it was necessary to have courage. To be true to their views, not to be afraid to express your thoughts by using symbols and allegorical language during the period of propaganda of socialist realism this could not go unpunished. M. Sapozhnikov died after a serious illness before the repressions of the 1930s, and his work was carefully eliminated from the history of Ukrainian fine art. Yu. Mikhailov was arrested in 1934 on trumped-up charges of preparing an armed uprising and was exiled to Kotlas, where he died in 1935.

Being undeservedly forgotten for many years of Soviet power, Mikhail Sapozhnikov and Yuhim Mikhailov left us a number of amazing paintings filled with lyric, music, wisdom, the symbolic sound of colour and light. We would like to recall the lines written by M. Sapozhnikov, which open the curtain 
of the mystery of painting symbolism: "With active contemplation, symbolic images, like waves, carry the viewer through the space of times of the manysided existence of man: in symbolic images, the viewer comes into contact with the eternal, timeless, immutable, inevitable. Staying in the world of images, like a spiritual bath cleans a person from everyday life, elevates him above his close, transitory and gives him the key to understanding the whole world. This is the essence of symbolic creativity and symbolic images" (Kulichikhin, 2018: 156).

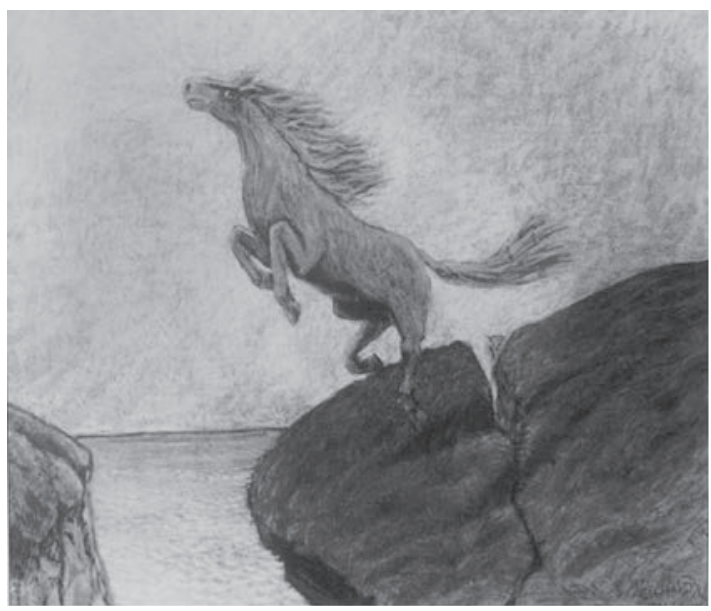

Fig. 11. Yu. Mikhailov, The Red Stallion, 1921.

Pastel, 48x5 Book reproduction "Yuchym Mykhailiv. Life and work" Pyadik, 2003

Conclusions. A comprehensive art history analysis of the paintings by Yukhim Mikhailov and Mikhail Sapozhnikov, using a semiotic and hermeneutic approach, as well as the use of general scientific methods, made it possible to draw conclusions about the symbolic and colouristic features of their works:

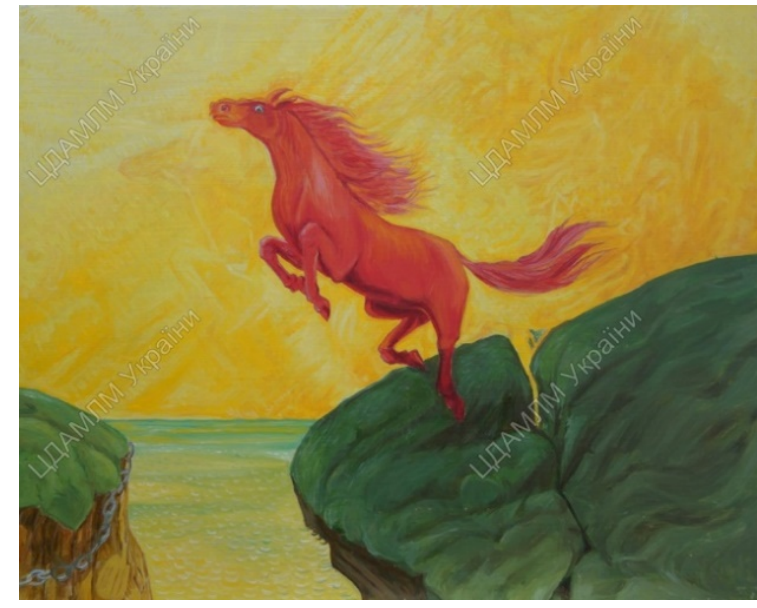

Fig. 12. E. Yankevich, The Red Stallion, 1996. Reconstruction of the painting by Yu. Mikhailov, destroyed in 1934 Museum collection of TsDAMLM of Ukraine (URL: https://csam.archives.gov. ua/2019/08/16/1454/)

1. All works are filled with deep philosophical meaning, which helps to understand the symbolism of the colouration of the paintings;

2. The colouration of the paintings of Ukrainian Symbolists is the main psychological and emotional component of the artistic image;

3. Conventionality, decorativeness, sometimes completely unexpected colour solutions are inherent in the colouration of the paintings of Ukrainian masters;

4. The combination in one work of the colouration, musicality, poetry (lyrics) is a feature of the painting of the Ukrainian Symbolists;

5. Symbolist artists convey deep inner religiosity, faith, spirituality through colour and light contrasts;

6 . The era of revolutions and global cultural changes brought new meanings to the symbolism of colour, the reflection of which we observe in the paintings of Ukrainian symbolist artists.

\section{BIBLIOGRAPHY}

1. Адаскина Н. Символизм в творчестве художников авангарда. Символизм в авангарде. Серия «Искусство авангарда 1910-1920 годов». Москва : Наука, 2003. С. 10-22.

2. Азизян И. Символистские истоки авангарда. Символ в поэзии авангарда. Символизм в авангарде. Серия «Искусство авангарда 1910-1920 годов». Москва : Наука, 2003. С. 23-33.

3. Басин Е. Семантическая философия искусства. Российская акад. наук, Институт философии, Акад. гуманитарных исследований. Москва : Гуманитарий, 2012. 348 с.

4. Богомазов О. Живопис та елементи. Киев : «Задумливий страус», 1996. 176 с.

5. Бранский В. П. Искусство и философия. Роль философии в формировании и восприятии художественного произведения на примере истории живописи. Калининград : Янтарный сказ, 1999. 704 с.

6. Гете И. В. Учение о цвете / Пер. с нем. В Лихтенштадта. Санкт-Петербург : Азбука-Аттикус, 2019. 256 с.

7. Иттен И. Искусство цвета / Пер. с нем. Л. Монахова. Москва : Изд. Д.Аронов, 2018. 96 с.

8. Кандинский В. В. Точка и линия на плоскости. О духовном в искусстве. Москва : Издательство АСТ, 2019. 352 с.

9. Куличихин В. В. Мир символов Михаила Сапожникова. Сапожников М.И. О символическом творчестве в искусстве. Днепр : Літограф, 2018. С. 155-157.

10. Лотман М., Минц 3. Статьи о русской и советской поэзии. Таллинн : Ээсти раамат, 1989. С. 41-75.

11. Малевич К. Черный квадрат. Санкт-Петербург : Азбука, Азбука-Аттикус, 2014. 286 с. 
12. Пальмов В. Н. Про мої роботи. Журнал лівої формації мистещтв «Нова Генерація». Харків : Держ. вид-во України, 1929. № 8. С. 27-29. URL: https://elib.nlu.org.ua/object.html?id=1149 (дата звернення: 10.05.2020)

13. П’ядик Ю. Юхим Михайлів: Життя і творчість. Київ : Мистецтво, 2003. 224 с.

14. Рембо А. Поэтические произведения в стихах и прозе : Сборник. Москва : Радуга, 1988. 544 с.

15. Рубцов Н. Н. Символ в искусстве и жизни: философские размышления. Москва : Наука, 1991. 176 с.

16. Соколюк Л. Поетика української культури у творчості Юхима Михайлова. Художня культура. Актуальні проблеми: наук. вісник. 2009. Вип 6. С. 491-496. URL: https://elib.nlu.org.ua/view.html?\&id=10565 (дата звернення: 02.07.2019).

17. Степовик Д. В. История украинской иконы Х-ХХ веков. Киев : Либідь, 1996. 440 с.

18. Сурина М. О. Цвет и символ в искусстве, дизайне и архитектуре. Ростов-на-Дону : Издательский центр «Март», «Феникс», 2010. 152 с.

19. Турчин В. Дух Символизма. Русское и западноевропейское искусство в контексте эпохи конца XIX - начала XX века : коллективная монография / Ред. М.В. Нащекина. Москва : Прогресс-Традиция, 2012. С. 85-143.

\section{REFERENCES}

1. Adaskyna, N. Symvolyzm v tvorchestve khudozhnykov avanharda. Symvolyzm v avanharde. Seryia Yskusstvo avanharda 1910-1920 hodov [Symbolism in the works of avant-garde artists. Symbolism at the forefront. Series Art of the avant-garde 1910-1920]. Moskva: Nauka, 2003. S. 10-22 [in Russian]

2. Azyzian, Y. Symvolystskye ystoky avanharda. Symvol v poezyy avanharda. Symvolyzm v avanharde. Seryia Yskusstvo avanharda 1910-1920 hodov [Symbolist origins of the avant-garde. A symbol in the poetry of the avant-garde. Symbolism at the forefront. Series Art of the avant-garde 1910-1920]. Moskva: Nauka, 2003. S 23-33. [in Russian]

3. Basyn, E. Semantycheskaia fylosofyia yskusstva. Rossyiskaia akad. nauk, Ynstytut fylosofyy, Akad. humanytarnykh yssledovanyi [Semantic philosophy of art]. Moskva: Humanytaryi, 2012. 348 s. [in Russian]

4. Bohomazov, O. Zhyvopys ta elementy [Painting and elements]. Kyev: Zadumlyvyi straus, 1996.176 s. [in Ukrainian].

5. Branskyi, V. P. Yskusstvo y fylosofyia. Rol fylosofyy $v$ formyrovanyy y vospryiatyy khudozhestvennoho proyzvedenyia na prymere ystoryy zhyvopysy [Art and philosophy. The role of philosophy in the formation and perception of a work of art on the example of the history of painting]. Kalynynhrad: Yantarni skaz, 1999. 704 s. [in Russian]

6. Hete, Y. V. Uchenye o tsvete [The doctrine of colour]. Per. s nem. V Lykhtenshtadta. Sankt-Peterburh: AzbukaAttykus, 2019. 256 s. [in Russian]

7. Ytten, Y. Yskusstvo tsveta [The art of colour]. Per. s nem. L. Monakhova. Moskva: Yzd. D. Aronov, 2018.96 s. [in Russian]

8. Kandynskyi, V. V. Tochka y lynyia na ploskosty. O dukhovnom v yskusstve [Point and line of planes. About the spiritual in art]. Moskva: Yzdatelstvo AST, 2019. 352 s. [in Russian]

9. Kulychykhyn, V. V. Myr symvolov Mykhayla Sapozhnykova. Prylozhenye: Sapozhnykov M.Y. O symvolycheskom tvorchestve v yskusstve [The world of symbols of Mikhail Sapozhnikov. Sapozhnikov MI About symbolic creativity in art]. Dnepr: Litohraf, 2018. S. 155-157. [in Russian]

10. Lotman, M., Mynts, Z. Staty o russkoi y sovetskoi poezyy [Articles on Russian and Soviet poetry]. Tallynn: Eesty raamat, 1989. S. 41-75. [in Russian]

11. Malevych, K. Chernyi kvadrat [Black square]. Sankt-Peterburh: Azbuka, Azbuka-Attykus, 2014. 286 s. [ in Russian]

12. Palmov, V. N. Pro moi roboty [About my works]. Zhurnal livoi formatsii mystetstv "Nova Heneratsiia". Kharkiv: Derzh. vyd-vo Ukrainy, 1929. № 8. S. 27-29. URL: https://elib.nlu.org.ua/object.html?id=1149 (date of the application: 10.05.2020) [in Ukrainian].

13. P'iadyk Yu. Yukhym Mykhailiv: Zhyttia i tvorchist [Yukhim Mikhailov: Life and work]. Kyiv: Mystetstvo, 2003. 224 s. [in Ukrainian].

14. Rembo A. Poetycheskye proyzvedenyia v stykhakh y proze [Poetic works in verse and prose]. Moskva: Raduha, 1988. 544 s. [in Russian]

15. Rubtsov N. N. Symvol v yskusstve y zhyzny: fylosofskye razmyshlenyia [Symbol in art and life: philosophical reflections]. Moskva: Nauka, 1991. 176 s. [in Russian]

16. Sokoliuk L. Khudozhnia kultura [Poetics of Ukrainian culture in the works of Yukhym Mykhailov]. Aktualni problemy: Nauk. Visnyk/In-t problem suchasnoho myst-va Akad. Myst-v Ukrainy. Kyiv: Khimdzhest, 2009. Vyp 6. S. 491-496. URL: https://elib.nlu.org.ua/view.html?\&id=10565 (date of the application: 02.07.2019) [in Ukrainian].

17. Stepovyk, D. V. Ystoryia ukraynskoi ykony X-XX vekov [History of the Ukrainian icon of X-XX centuries]. Kyev: Lybid, 1996. 440 s. [in Ukrainian].

18. Suryna, M. O. Tsvet y symvol v yskusstve, dyzaine y arkhytekture [Colour and symbol in art, design and architecture]. Rostov-na-Donu: Yzdatelskyi tsentr Mart, Fenyks, 2010. 152 s. [in Russian]

19. Turchyn, V. Dukh Symvolyzma. Russkoe y zapadnoevropeiskoe yskusstvo v kontekste epokhy kontsa XIX - nachala XX veka [Spirit of Symbolism. Russian and Western European art in the context of the late XIX - early XX century]. Kollektyvnaia monohrafyia. Red. M. V. Nashchekyna. Moskva: Prohress-Tradytsyia, 2012. S. 85-143. [in Russian] 